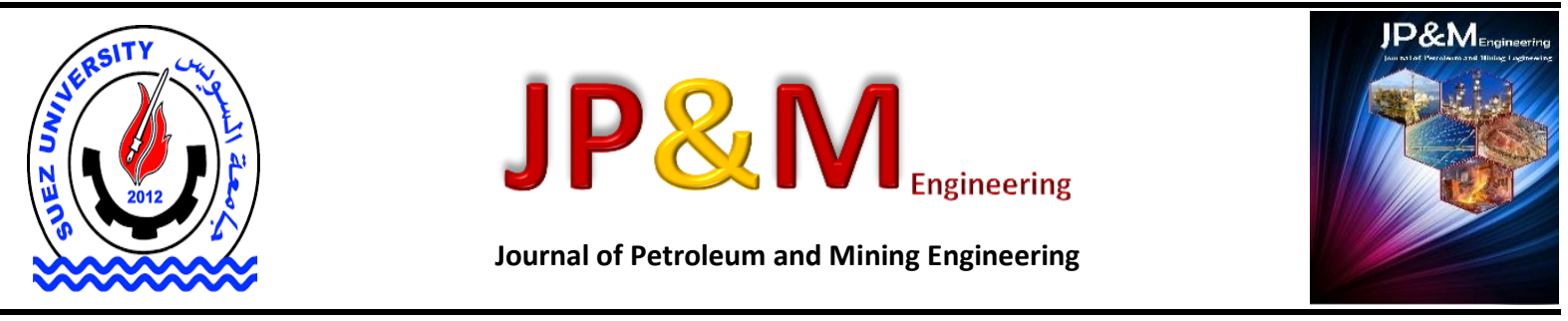

\title{
Joint Addition of Zirconium, Titanium and Chromium to Commercial Pure
}

\section{Aluminium}

\author{
Aboraia, M.S. ${ }^{*}$, Gad- Elrab, H. G². and Abdalla, G. A. ${ }^{1}$ \\ ${ }^{1}$ Mining and Metallurgical Engineering Department, Faculty of Engineering, Assiut University, Assiut, \\ ${ }^{2}$ Nuclear Materials Authority- Egypt. \\ *Corresponding author: maboraia@aun.edu.eg
}

\section{Article Info \\ Received 23 Jun. 2020 \\ Revised 11 Jul. 2020 \\ Accepted 23 Jul. 2020}

\section{Keywords}

joint addition, $\mathrm{Zr}$-Ti-Cr, grain refinement, aluminium.

\begin{abstract}
The effect of joint addition of $\mathrm{Zr}, \mathrm{Ti}$ and $\mathrm{Cr}$ on the grain refinement of commercial pure aluminium ( $99.7 \% \mathrm{Al}$ ) has been investigated by optical microscopy and scanning electron microscopy (SEM) as well as Energy Dispersive X-ray Spectroscopy (EDS). It was found that joint addition of $0.15 \mathrm{wt} \% \mathrm{Zr}$ and $0.025 \mathrm{wt} \% \mathrm{Ti}$ to $\mathrm{Al}$ can result in a remarkable refinement with an average grain size of $102 \mu \mathrm{m}$. It was found the optimum addition level of $\mathrm{Ti}$ to be $0.025 \mathrm{wt} \%$ in the presence of $0.1 \% \mathrm{Zr}$ and any increase in the Ti beyond $0.025 \mathrm{wt} \%$ results in coarse grain size. Joint additions of $0.15 \mathrm{wt} \% \mathrm{Zr}, 0.025 \mathrm{wt} \% \mathrm{Ti}$ and $0.15 \mathrm{wt} \% \mathrm{Cr}$ to Al facilitate better grain refinement and the average grain size was $75 \mu \mathrm{m}$. The grain refining performance of joint addition of $0.1 \mathrm{wt} . \% \mathrm{Zr}$ and different additions of either $\mathrm{Ti}$ or $\mathrm{Cr}$ is higher than refining with zirconium alone. EDS and SEM analysis of the precipitated phases observed at or near the centers of the refined aluminium with joint addition of $\mathrm{Zr}$ and $\mathrm{Ti}$ was found to be $\mathrm{Al}_{3}\left(\mathrm{Zr}_{1-\mathrm{x}} \mathrm{Ti}_{\mathrm{x}}\right)$. These $\mathrm{Al}_{3}\left(\mathrm{Zr}_{1-\mathrm{x}} \mathrm{Ti}_{\mathrm{x}}\right)$ particles act as heterogeneous nucleation sites for $\alpha$-Al during solidification and resulted in better grain refinement.
\end{abstract}

\section{Introduction}

Aluminium is the most abundant element in the earth's crust. Pure aluminium possesses many advantages to be used extensively in industry, such as good electrical conductivity which superior to copper, better heat conductivity, lower density and higher plasticity [1-3]. Depending on the conductivity of the aluminium alloy, the current carrying capacity of some aluminium alloys is about twice (per unit mass) compared to copper [4].

The wide applications of aluminium and its alloys in industry are limited for the coarse grain size which degrades the mechanical properties $[5,6,7]$. Grain refinement is a favorite technique to improve simultaneously the plasticity and strength of metallic materials. So that grain refining of aluminum is a key technique in aluminum processing. Now a days, there have been a number of techniques for aluminum grain refining. Grain refining techniques can be classified into four categories as follows: the addition of grain refiner, grain refining by stirring and vibration during solidification, rapid solidification and severe plastic deformation [8].

The widespread usage of grain refinement in the aluminium industry is due to that grain refinement is one of the predominant techniques in controlling the quality of Al castings [5,6-9]. Formation of fine equiaxed grains during solidification is a result of grain refinement. Fine equiaxed grains leads to many benefits such as, uniform and improved mechanical properties throughout the material, imparts high yield strength, good extrudability, reduced ingot cracking and improved resistance to hot tearing, and gives a more uniform distribution of secondary phases and microporosity on a fine scale [1014]. The most common grain refiners used for aluminium and aluminium based alloys are the transition metals such as titanium (Ti), vanadium (V), zirconium ( $\mathrm{Zr}$ ), tantalum (Ta) etc. These transition metals are used to refine aluminium and its alloys in the form of master alloys of sort $\mathrm{Al}-\mathrm{B}, \mathrm{Al}-\mathrm{Ti}-\mathrm{B}, \mathrm{Al}-\mathrm{Ti}-\mathrm{C}$ of different $\mathrm{Ti} / \mathrm{B}$ and $\mathrm{Ti} / \mathrm{C}$ ratios, $\mathrm{Al}-\mathrm{Zr}$ and Al-SC $[8,15-18]$. The grain refinement mechanisms are based on heterogeneous nucleation of aluminium grains on inoculant particles. According to the heterogeneous nucleation theory, the effectiveness of grain refining is governed by two factors: number of particles nuclei in a unit of melt volume and effectiveness of the inoculate action of particles nuclei. The latter factor depends on the similarity of crystal lattices of a particlenucleus and matrix in terms of size and structure. The similarity in lattice types plays a decisive role in grain refining. Increasing the number of nucleating particles results in a fine-grained structure, so that a large number of crystals are formed, which soon impinge on each other and prevent each other from further growth $[14,19,20]$. Grain refinement of Aluminium is affected by the percentage and type of grain refiners, the holding time [21] and the size of added grain refiner [22]. 
The aim of this work is to investigate the performance of joint additions of $\mathrm{Al}-\mathrm{Zr}-\mathrm{Ti}$ and $\mathrm{Al}-\mathrm{Zr}-\mathrm{Ti}-\mathrm{Cr}$ as grain refiners for commercial pure aluminium (99.7\%).

\section{Experimental procedures}

Commercial pure aluminium (99.7\%) was the starting material for all grain refinement experiments. Al-Zr master alloy was used as the grain refiner. This master alloy was prepared by in-situ reduction of zirconium oxide $\left(\mathrm{ZrO}_{2}\right)$ with excess aluminium in the presence of cryolite flux. Al-Cr master alloy was obtained from Aluminium Company of Egypt (EGYPTALUM). A commercially pure Al was melted in a graphite crucible using electrical resistance furnace at $740{ }^{\circ} \mathrm{C}$. After addition of the grain refiners to molten aluminium, the melt was stirred with a graphite rod for $60 \mathrm{~s}$ to homogenize the melt. The molten aluminium was kept for $90 \mathrm{~s}$ in the furnace then poured into a steel ring of 75-mm diameter, $4 \mathrm{~mm}$ wall thickness and $25 \mathrm{~mm}$ height with a base of refractory brick. After solidifying and cooling, the specimens were prepared for macrograph by grinding, polishing and etching in solution contains $15 \mathrm{~mm} \mathrm{HF}, 15 \mathrm{~mm} \mathrm{HNO}_{3}, 45 \mathrm{~mm} \mathrm{HCl}$ and $25 \mathrm{~mm}$ distilled water. For measuring the grain size of the grain refined specimens, specimens were ground and polished then the micrograph was revealed using Keller's reagent to reveal their grain boundaries. At least 40 pictures were taken for each sample using Olympus PME M021 Optical microscope attached with digital camera, which were used in measuring the grain size with the linear intercept method (ASTM-E112-13).

SEM image was examined by a Scanning Electron Microscope (SEM) using a Joel- JSM-5400 LV -SEM equipped with EDX analyzer at Electron microscopy unitAssiut university.

\section{Results and Discussions}

\section{Joint Addition of $0.1 \% \mathrm{Zr}$ and Various Ti Additions}

Figure 1 (a) shows the macrostructure of unrefined commercial pure aluminium with average grain size of approximately $1100 \mu \mathrm{m}$. Unrefined aluminium exhibits fine columnar structure at the periphery and coarse equiaxed grains at the center of the specimen. Figure1 (bf) shows the macrostructures of commercial pure aluminium specimens inoculated with joint addition of 0.1 $\% \mathrm{Zr}$ and various additions of $\mathrm{Ti}$ at $740 \mathrm{C}^{\circ}$ and holding time of 90 seconds. It is obvious that the macrostructure of the commercial pure aluminium grain refined with joint addition of $\mathrm{Ti}$ and $\mathrm{Zr}$ shows equiaxed, fine and uniform grains. Wang et al [23] found that $\mathrm{Al}_{3} \mathrm{Zr}$ particles formation are highly potent nucleants for Aluminium.

The precipitated phases observed at or near the centers of the refined commercial pure aluminium grains refined with joint addition of $\mathrm{Zr}$ and $\mathrm{Ti}$ were studied by SEM micrographs at larger magnification (5000x) as shown in Figure 2(a). It is clear that these particles exhibit petal-like morphology. Figure 2(b) shows EDX analysis for the phase. The composition of these particles was found to fit to $\mathrm{Al}_{3}\left(\mathrm{Zr}_{1-\mathrm{x}} \mathrm{Ti}_{\mathrm{x}}\right)$. These particles are to act as heterogeneous nucleation sites for Al during solidification.

The reason of fine structure is related to formation of $\mathrm{Al}_{3}\left(\mathrm{Zr}_{1-\mathrm{x}}, \mathrm{Ti}_{\mathrm{x}}\right)$ particles which act as potent nucleating sites for Al. The average grain size decreases as the addition level of $\mathrm{Ti}$ increases from 0.01 to $0.025 \mathrm{wt} . \%$ then slightly increases at higher $\mathrm{Ti}$ additions. The grain refining performance of joint addition of $0.1 \mathrm{wt} . \% \mathrm{Zr}$ and different additions of $\mathrm{Ti}$ is higher compared with refining with zirconium alone [24,25]. Figure3 (a-e) shows the microstructures of commercial purity aluminium with joint addition of $0.1 \mathrm{wt}$. \% $\mathrm{Zr}$ and the different addition levels of $\mathrm{Ti}(0.01,0.015,0.02,0.025$, and 0.03 wt. \%).
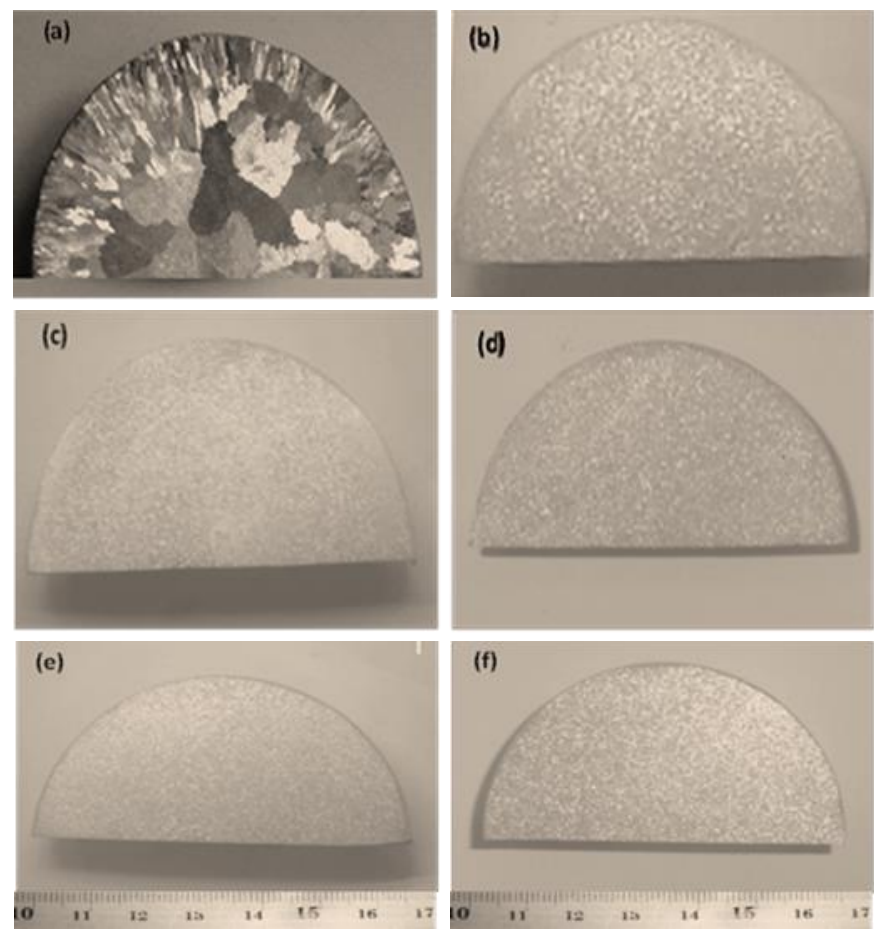

Figure 1 Optical macrographs of commercially pure Al grain refined with $0.1 \mathrm{wt}$. \% Zr and different addition levels of Ti: (a) unrefined; (b) 0.01 ; (c) 0.015 ; (d) 0.02 ; (e) 0.025 (f) $0.03 w t . \% ~ T i$.
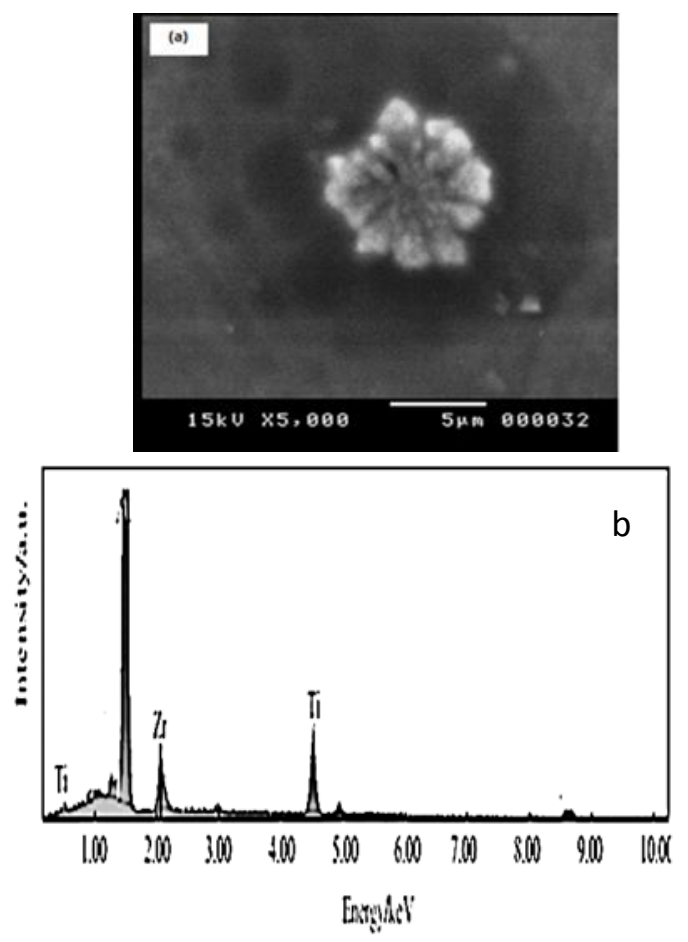

Figure 2 (a) SEM image of $\mathrm{Al}_{3}\left(\mathrm{Zr}_{x}, \mathrm{Ti}_{1-\mathrm{x}}\right)$, (b) EDX spectrum at the particle center. 
It can be seen from Figure 1 that there is a significant conversion from columnar grain structure of the commercial purity aluminium to equiaxed grain structure. Increasing the addition of $\mathrm{Ti}$ simultaneously with $0.1 \mathrm{wt} . \%$ $\mathrm{Zr}$, the aluminium microstructure get more refined. Figure 4 displays the average grain size variation of the grain refined aluminium as a function of addition level of $\mathrm{Ti}$, which clearly shows the grain refining performance of joint addition of titanium and zirconium. It can be noted that, the average grain size of the refined aluminium with constant addition of $\mathrm{Zr}(0.1 \%)$ is decreased to 155,144 , $135,125 \mu \mathrm{m}$, respectively with increasing the percentage of Ti to $0.01,0.015,0.02$, and 0.025 , respectively. The optimum addition level of Ti with $0.1 \% \mathrm{Zr}$ is $0.025 \%$ at which the average grain size of aluminium is $125 \mu \mathrm{m}$. At higher concentration of $\mathrm{Ti}$ the average grain size of aluminium increases. This behavior agrees with the result which obtained by Jaradeh et al. [26], where not all $\mathrm{Ti}_{3} \mathrm{Al}$ particles are dissolved. Zhang et al [27] found that excess $\mathrm{Ti}$ addition tend to form large particles of $\mathrm{Ti}_{3} \mathrm{Al}$ intermetallic.
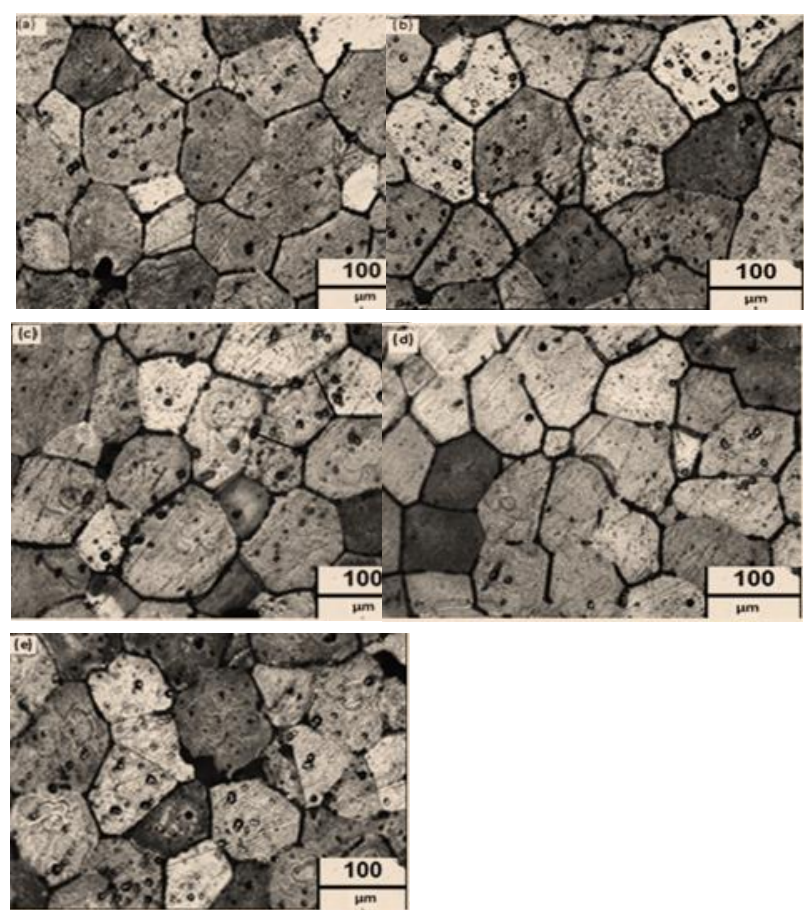

Figure 3 Optical micrographs of grain refined aluminium by addition of $0.1 \mathrm{wt}$. \% Zr and different addition levels of Ti: (a) 0.01; (b) 0.015; (c) 0.02; (d) 0.025; (e) 0.03 wt. \% Ti.

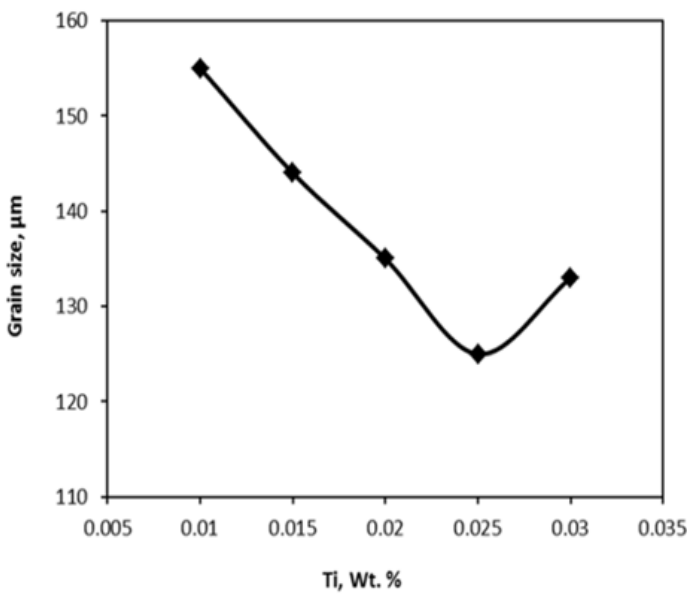

Figure 4 Effect of joint addition of 0.1 wt. \% Zr and various addition levels of Ti on grain size.
Joint Addition of 0.15 wt. \%Zr and Various Ti Additions

The effect of joint addition of several contents of Ti and $0.15 \mathrm{wt}$. \% Zr on the grain refinement of commercial purity aluminium is illustrated in Figure 5 (a-e), which shows the macrostructure of the refined aluminium. It can be noted that, the joint addition of $0.15 \mathrm{wt}$. \% $\mathrm{Zr}$ and $0.01,0.015$, 0.02 and $0.025 \mathrm{wt}$. \% Ti can greatly refine the commercial purity aluminium. The refining effect is markedly pronounced with the Ti addition of $0.01 \mathrm{wt}$. \%, then slowly with increasing Ti content from 0.01 to 0.025 wt. \%

Figure 6(a-e) indicates the micrographs of the grain refined aluminium by joint addition of $0.15 \mathrm{wt} . \% \mathrm{Zr}$ and various addition levels of $\mathrm{Ti}(0.01,0.015,0.02$ and 0.025 wt.\%). It can be revealed that the refined commercial purity aluminium presents the equiaxed grain structure and the finest grain structure is obtained at joint addition of $0.15 w t . \% \mathrm{Zr}$ and $0.025 \mathrm{wt}$. \% Ti as shown in Figure 5(d).
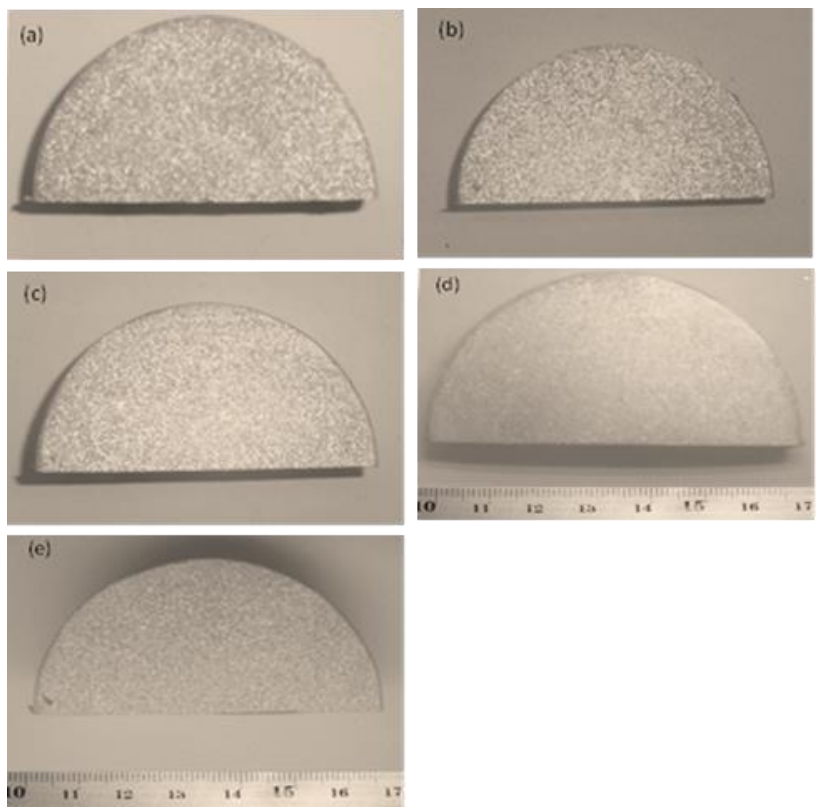

Figure 5 Optical macrographs of commercially pure Al grain refined with $0.15 \mathrm{wt} . \% \mathrm{Zr}$ and different addition levels of Ti: (a) 0.01 ; (b) 0.015 ; (c) 0.02 ; (d) 0.025 ; (e) $0.03 w t . \% ~ T i$.

It is important matter to determine the optimum addition level of the grain refiners, at which, a more uniform distribution of intermetallic phases and finer equiaxed grain structure in comparison with unrefined aluminium can be achieved. Figure 7 shows the effect of various concentrations of Ti with $0.15 \mathrm{wt} . \% \mathrm{Zr}$ added to aluminium melt prior to solidification. By joint addition of $0.15 \% \mathrm{Zr}$ and $0.01 \mathrm{Ti} \%$, the average grain size of aluminium reduces from $1100 \mu \mathrm{m}$ to $150 \mu \mathrm{m}$. Joint addition of $0.15 \% \mathrm{Zr}$ and $0.015 \mathrm{Ti} \%$ decreases the average grain size of aluminium to $141 \mu \mathrm{m}$. Further addition of $0.15 \% \mathrm{Zr}$ and $0.02 \% \mathrm{Ti}$ reduces the average grain size of aluminium to $126 \mu \mathrm{m}$. The optimum amounts of $\mathrm{Zr}$ and $\mathrm{Ti}$ added to aluminium melt are $0.15 \% \mathrm{Zr}$ and $0.025 \% \mathrm{Ti}$. At this optimum addition level, the average grain size of aluminium drastically reduced from 1100 to $102 \mu \mathrm{m}$. Increasing the concentration of $\mathrm{Ti}$ to $0.025 \%$ with $0.15 \% \mathrm{Zr}$ increases the average grain size of aluminium to $122 \mu \mathrm{m}$. The variation in grain size represents more produced effective nucleation sites in the grain refined aluminium specimens. $\mathrm{The} \mathrm{Al}_{3}\left(\mathrm{Zr}_{1-\mathrm{x}}, \mathrm{Ti}_{\mathrm{x}}\right)$ particles act as potent nucleating sites for 
$\alpha-A l$ and resulted in finer grains which are caused by the grain refining effect of joint addition of $\mathrm{Zr}$ and $\mathrm{Ti}$.
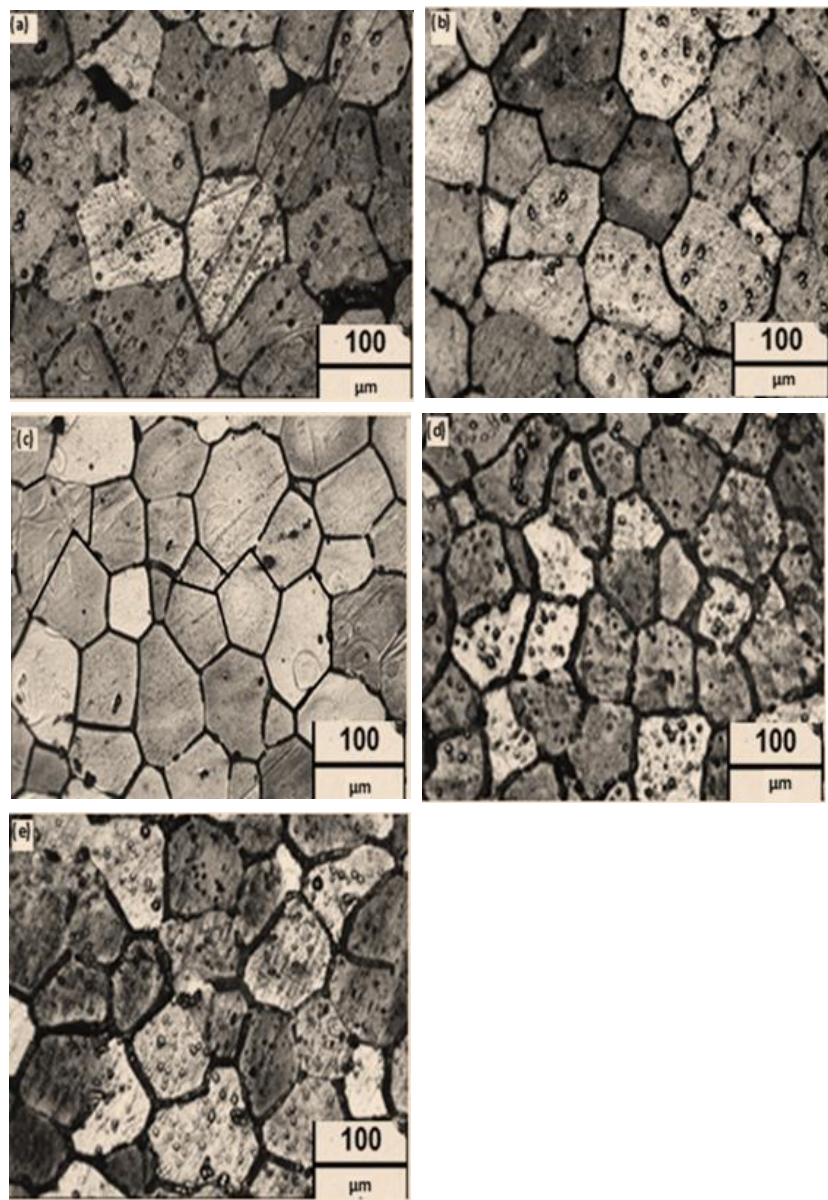

Figure 6 Optical micrographs of grain refined aluminium by addition of 0.15 wt. \% Zr and different additions of Ti: (a) 0.01 ; (b) 0.015 ; (c) 0.02 ; (d) 0.025 ; (e) 0.03 wt. \% Ti.

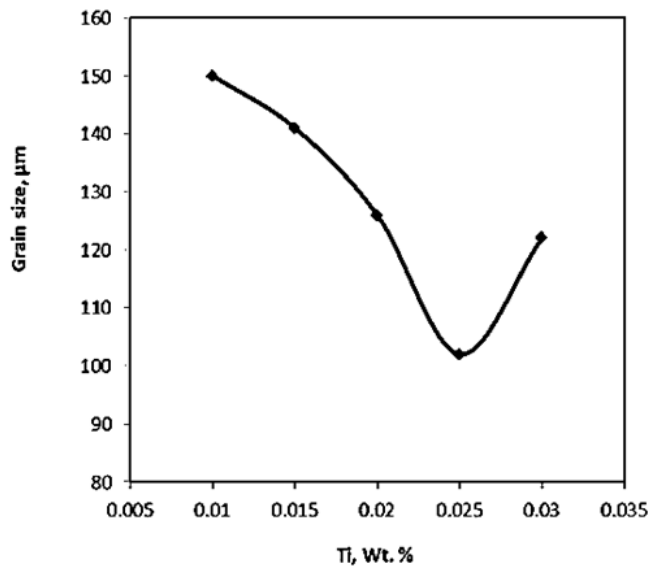

Figure 7 Effect of joint addition of $0.15 \mathrm{wt}$ \% $\mathrm{Zr}$ and various addition levels of $\mathrm{Ti}$ on grain size

\section{Joint Addition of $0.2 \% \mathrm{Zr}$ and Various Ti Additions}

Figure $8(a-d)$ shows the macrographs of the refined aluminium with $0.2 \mathrm{wt}$. \% $\mathrm{Zr}$ and different $\mathrm{Ti}$ additions $(0.01,0.015,0.02$ and $0.025 w t$. \%, respectively). It can be observed that, complete conversion of coarse columnar grain structure to fine equiaxed grains occurs. As the amount of $\mathrm{Ti}$ is increased from 0.01 to $0.02 \mathrm{wt}$. \%, the average grain size became finer then increased slightly by further addition of $\mathrm{Ti}$. It is clear that the macrostructure of the refined aluminium specimens by joint addition of
0.2 wt. \% $\mathrm{Zr}$ and different $\mathrm{Ti}$ additions are coarsened slightly compared to that refined by $0.15 \mathrm{wt}$. $\% \mathrm{Zr}$ and different Ti additions.
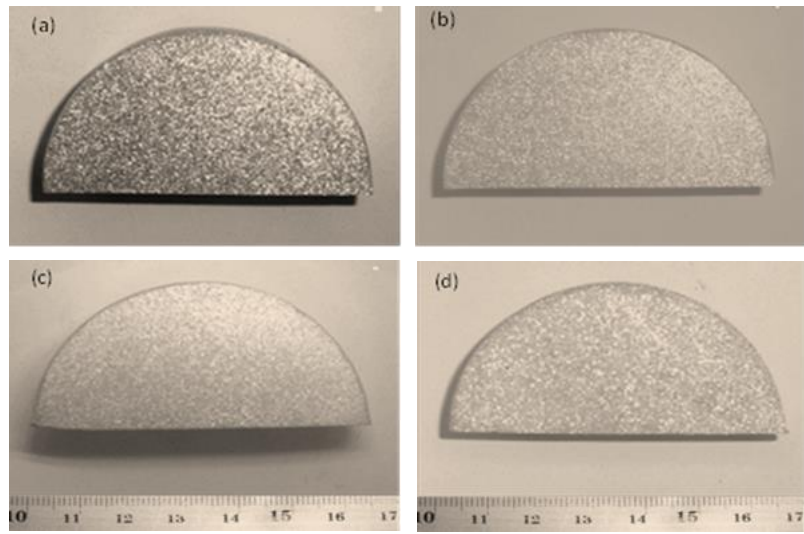

Figure 8 Optical macrographs of refined Aluminium with $0.2 \mathrm{wt}$. $\% \mathrm{Zr}$ and different addition levels of Ti: (a) 0.01 ; (b) 0.015; (c) 0.02 ; (d) $0.025 \mathrm{wt} . \% \mathrm{Ti}$

The representative microstructures of grain refined aluminium by joint addition of $0.2 \mathrm{wt}$. \% $\mathrm{Zr}$ and different amount of Ti are given in Figure 9 (a-d).
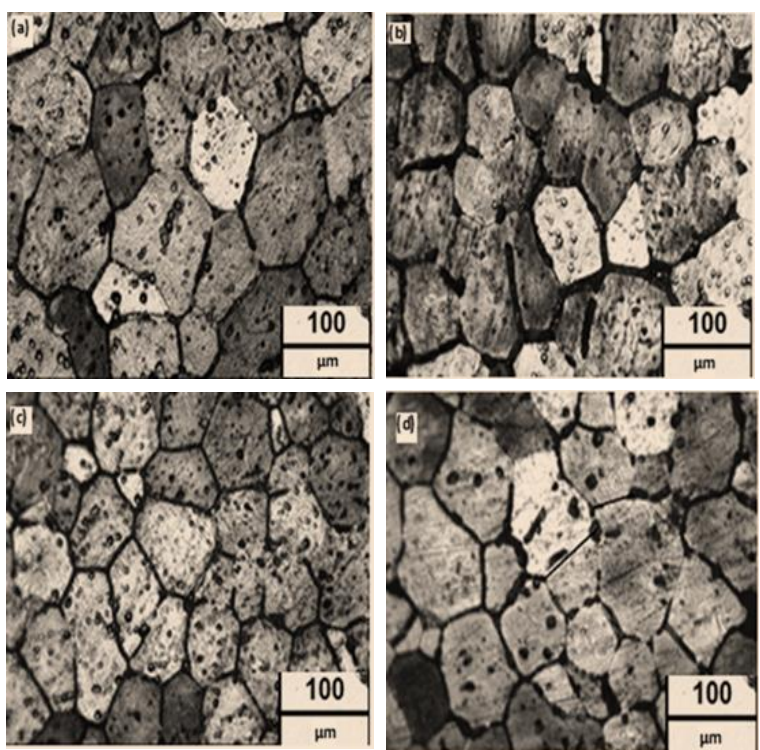

Figure 9 Optical micrographs of grain refined aluminium by addition of $0.2 \mathrm{wt}$. \% $\mathrm{Zr}$ and different addition levels of Ti: (a) 0.01 ; (b) 0.015; (c) 0.02; (d) 0.025 wt. \% Ti.

From these micrographs, it is clear that the grain morphologies of all the specimens exhibit an equiaxed microstructure and no dendrites were observed. The average grain size of refined aluminium with joint addition of $0.2 \% \mathrm{Zr}$ and $\mathrm{Ti}(0.01,0.015,0.02$, and $0.025 \%$, respectively) is plotted in Figure 10. It can be noted that, with joint addition of $0.2 \mathrm{wt} . \% \mathrm{Zr}$ and $0.01 \% \mathrm{Ti}$, the average grain size of aluminium reduced significantly to $140 \mu \mathrm{m}$. Increasing the addition to $0.2 \mathrm{wt}$. $\% \mathrm{Zr}$ and 0.015 $\% \mathrm{Ti}$, the grains of aluminium can get a better refining effect and the average grain size reduced to $126 \mu \mathrm{m}$. By addition of $0.2 \mathrm{wt} \% \mathrm{Zr}$ and $0.02 \% \mathrm{Ti}$ the grain size reduced to $114 \mu \mathrm{m}$. Further addition of Ti and $0.2 \mathrm{wt}$. $\%$ $\mathrm{Zr}$ leads to a slight increase in the average grain size of aluminium. 


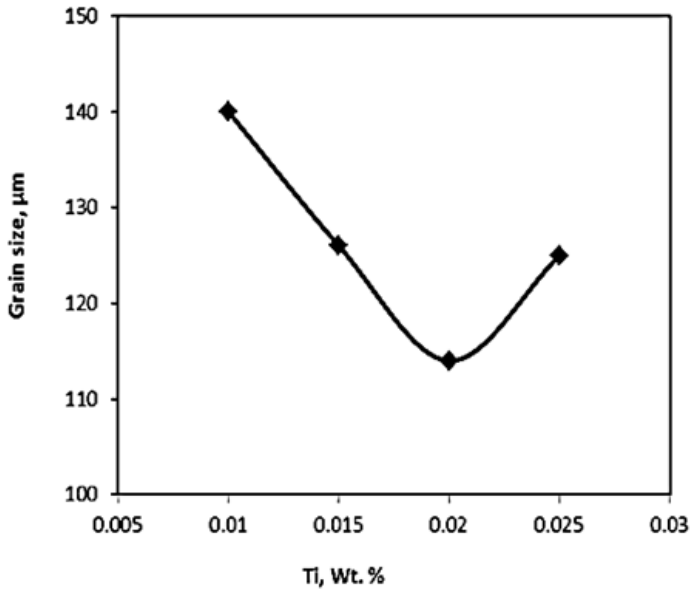

Figure 10 Effect of joint addition of $0.2 \mathrm{wt}$. \% $\mathrm{Zr}$ and various addition levels of $\mathrm{Ti}$ on grain size.

\section{Joint Addition of 0.15 wt.\%Zr, 0.025 wt.\%Ti and Various Cr Additions}

Figure $11(a-d)$ presents the macrostructure of commercial Al specimens, which were refined by joint addition of 0.15 wt. \% Zr, 0.025 wt. \% Ti and different addition levels of $\mathrm{Cr}$. It is shown that all refined specimens exhibit fine equiaxed grains. It was found that $\mathrm{Cr}$ dissolved in liquid $\mathrm{Al}$ in small quantities and alters the surface tension of $\mathrm{Al}$ to improve the wettability of the grain refining constituents of the grain refiners [28].

Figure 12 (a-d) shows the micrographs of refined aluminium with joint addition of 0.15 wt. \% Zr, 0.025 wt. $\% \mathrm{Ti}$ and different addition levels of $\mathrm{Cr}$. It can be observed from Figure 12 (a-c) that, as the addition level of $\mathrm{Cr}$ increases up to $0.15 \mathrm{wt}$. \%, the microstructure of $\mathrm{Al}$ specimens get more refined. Further addition of $\mathrm{Cr}$ slightly increases the grain size of the refined Al. This is due to that, increasing the addition level of $\mathrm{Cr}$ accelerates the dissolution rate of active nucleating sites $[14,28]$.
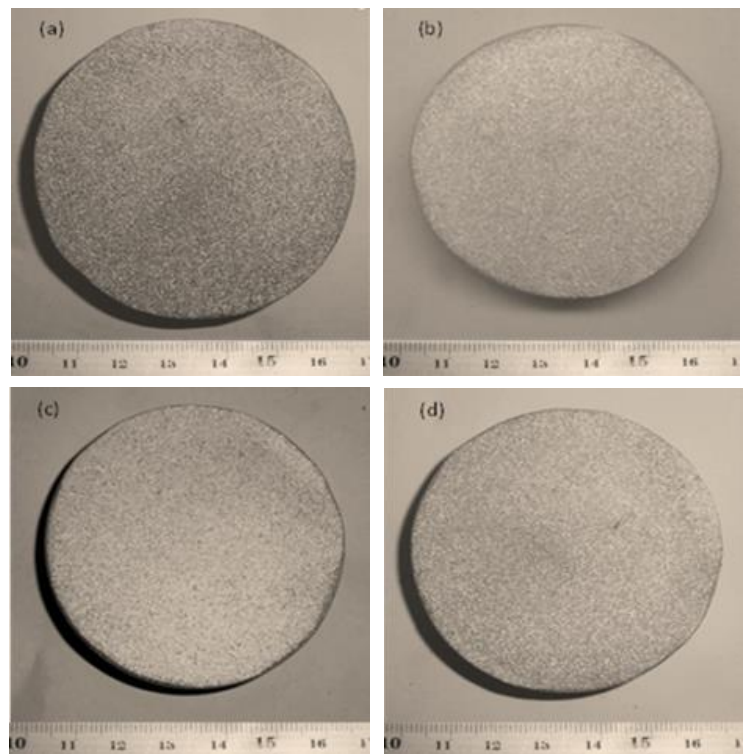

Figure 11 Optical macrographs of refined aluminium with joint addition of $0.15 \mathrm{wt} . \% \mathrm{Zr}, 0.025 \mathrm{wt}$. \% Ti and different addition levels of $\mathrm{Cr}$ : (a) 0.05 ; (b) 0.1 ; (c) 0.15 ; (d) 0.2 wt. \%Cr.
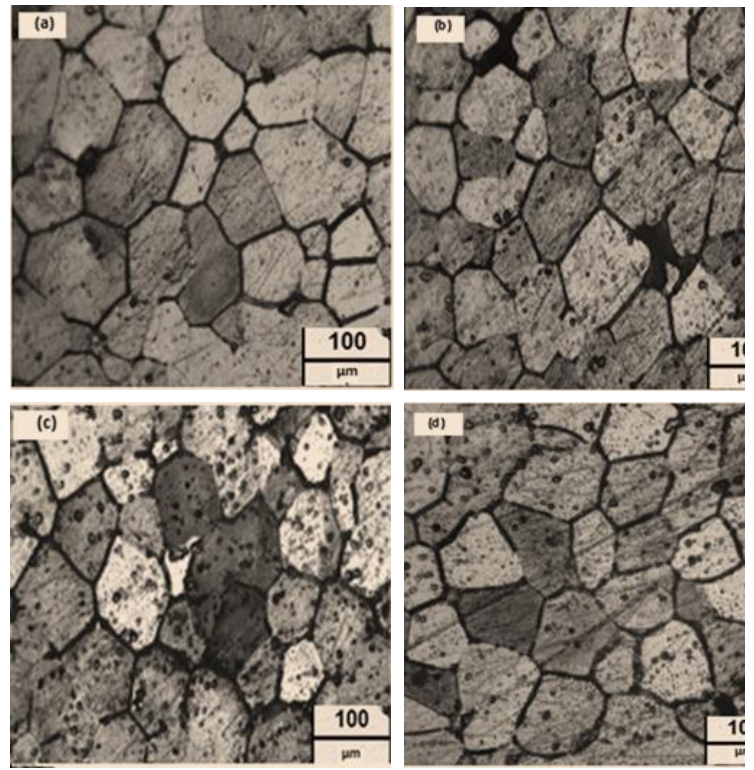

Figure 12 Optical micrographs s of commercially pure Al grain refined with joint addition of $0.15 \mathrm{wt} . \% \mathrm{Zr}$, $0.025 \mathrm{wt}$. \% Ti and different addition levels of $\mathrm{Cr}$ : (a) 0.05 ; (b) 0.1 ; (c) 0.15 ; (d) 0.2 .

Figure 13 shows the addition levels of $\mathrm{Cr}$ versus the average grain size of the refined Al. It can be seen that, joint addition of $0.15 \mathrm{Zr}, 0.025 \mathrm{Ti}$ and $0.05 \mathrm{wt}$ \% $\mathrm{Cr}$ drastically reduces the average grain size of Al to $93 \mu \mathrm{m}$. Joint addition of $0.15 \mathrm{Zr}, 0.025 \mathrm{Ti}$ and 0.1 wt. \% $\mathrm{Cr}$ facilitates better grain refinement, where the average grain size of $\mathrm{Al}$ is $82 \mu \mathrm{m}$. A remarkable refinement with an average grain size about $75 \mu \mathrm{m}$ can be obtained with joint addition of $0.15 \mathrm{Zr}, 0.025 \mathrm{Ti}$ and 0.15 wt. \% Cr. Joint addition of $0.15 \mathrm{Zr}, 0.025 \mathrm{Ti}$ and $0.2 \mathrm{wt}$. \% $\mathrm{Cr}$ results in increasing the average grain size to $80 \mu \mathrm{m}$.

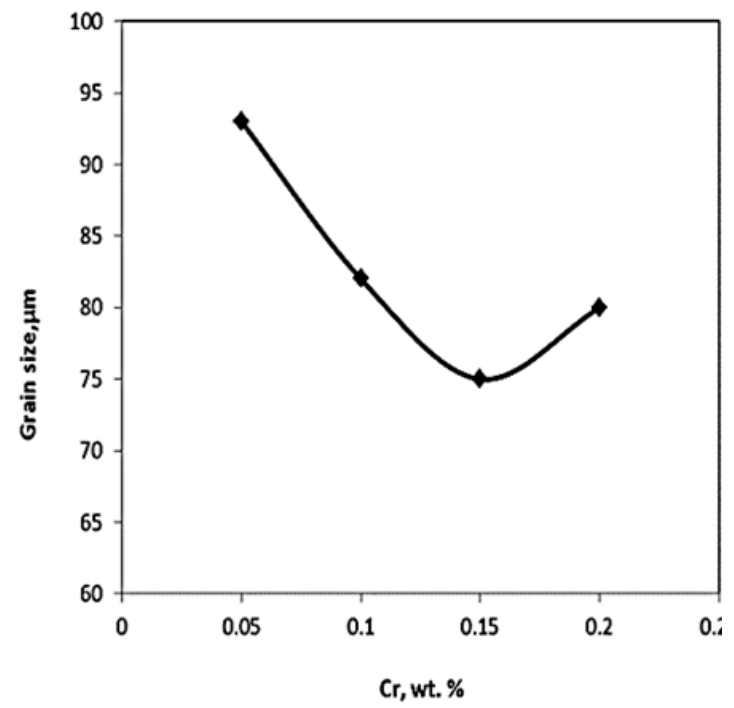

Figure 13 Effect of joint addition of 0.15 wt. \% Zr, 0.025 wt. \% Ti and different addition levels of $\mathrm{Cr}$ on grain size.

\section{Conclusions}

The effect of joint additions of zirconium, titanium and chromium on the grain refinement of commercial pure aluminium $(99.7 \%)$ is investigated by microstructure, macrostructure observation and grain size measuring. The following conclusions can be drowned: 
1- $\mathrm{Al}_{3}\left(\mathrm{Zr}_{1-\mathrm{x}} \mathrm{Ti}_{\mathrm{x}}\right)$ phase which precipitated at or near the centers of the refined grains in case of joint addition of $\mathrm{Zr}$ and $\mathrm{Ti}$ was observed by SEM and confirmed by EDX.

2- $A l_{3}\left(Z r_{1-x} T_{x}\right)$ phase has a petal like morphology and acts as a substrate for heterogeneous nucleation sites for the refined aluminium.

3- Joint addition of 0.15 wt. \% $\mathrm{Zr}$ and 0.025 wt. $\%$ Ti effectively refined the microstructure of aluminium with average grain size of 102 $\mu \mathrm{m}$. This is due to $\mathrm{Ti}$ substitutes for zirconium in $\mathrm{Al}_{3} \mathrm{Zr}$ forming $\mathrm{Al}_{3}\left(\mathrm{Zr}_{1-\mathrm{x}} \mathrm{Ti}_{\mathrm{x}}\right)$, which reduces the lattice parameters mismatch between aluminium and $\mathrm{Al}_{3} \mathrm{Zr}$ improving the grain refining efficiency.

4- Joint addition of $0.15 \mathrm{wt} . \% \mathrm{Zr}, 0.02 \mathrm{wt}$. \% Ti and $0.15 \mathrm{wt}$. \% $\mathrm{Cr}$ drastically reduces the average grain size of commercial pure aluminium from 1100 to $75 \mu \mathrm{m}$. This is attributed to that, $\mathrm{Cr}$ act as a grain refiner for aluminium and as a substrate for nucleating $\mathrm{Al}_{3}\left(\mathrm{Zr}_{1-\mathrm{x}} \mathrm{Ti}_{\mathrm{x}}\right)$ particles.

\section{Funding sources}

This research received no external funding.

\section{Conflicts of interest}

There are no conflicts to declare.

\section{References}

[1]. X.Du, Study on ageing and creep of $\mathrm{Al}-0.1 \mathrm{Zr}$ alloy. Materials Science and Engineering: A. 432(1-2) (2006) 8489.

[2]. Z.Henghua, T. Xuan, S. Guangjie and X. Luoping, Refining mechanism of salts containing $\mathrm{Ti}$ and $\mathrm{B}$ elements in purity aluminum. Journal of materials processing technology, 180(1-3) (2006) 60-65.

[3]. J. Omotoyinbo and I. Oladele, The effect of plastic deformation and magnesium content on the mechanical properties of 6063 aluminium alloys. Journal of Minerals and Materials Characterization and Engineering, 9(06) (2010) 539.

[4]. R. Yanniello, P. Pollak, and J. Rooks, "Technical and economic considerations of aluminum conductors, in Proc. Annu. Pulp Paper Ind. Tech. Conf. (2007) 63-67.

[5]. P. Li, S. Liu, L. Zhang , X. Liu, Grain refinement of A356 alloy by Al-Ti-B-C master alloy and its effect on mechanical properties. Materials \& Design 47 (2013) 522528.

[6]. D. Qiu, J. Taylor, M.-X. Zhang, Understanding the copoisoning effect of $\mathrm{Zr}$ and $\mathrm{Ti}$ on the grain refinement of cast aluminum alloys. Metallurgical and Materials Transactions A, 41(13) (2010) 3412-3421.

[7]. M.Vandyoussefi, A. Greer, Application of cellular automaton-finite element model to the grain refinement of directionally solidified Al-4.15 wt\% Mg alloys. Acta Materialia, 50(7) (2002) 1693-1705.

[8]. R.G. Guan, D. Tie, A Review on Grain Refinement of Aluminum Alloys: Progresses, Challenges and Prospects. Acta Metallurgica Sinica (English Letters). 30(5) (2017) 409-432.
[9]. T. Chandrashekar, M. Muralidhara, K.T. Kashyap, P.Rao, , Effect of growth restricting factor on grain refinement of aluminum alloys. The International Journal of Advanced Manufacturing Technology. 40 (2009).234-241.

[10]. M. Alipour , M. Emamy, S.H. Seyed Ebrahimi, M. Azarbarmas, M. Karamouz, J.Rassizadehghani , Effects of pre-deformation and heat treatment conditions in the SIMA process on properties of an $\mathrm{Al}-\mathrm{Zn}-\mathrm{Mg}-\mathrm{Cu}$ alloy modified by $\mathrm{Al}-8 \mathrm{~B}$ grain refiner. Materials Science and Engineering: A, 528(13-14) (2011) 4482-4490.

[11]. N. Pourkia, , M. Emamy, H. Farhangi, S.H. Ebrahimi, The effect of $\mathrm{Ti}$ and $\mathrm{Zr}$ elements and cooling rate on the microstructure and tensile properties of a new developed super high-strength aluminum alloy. Materials Science and Engineering: A, 527(20) (2010) 5318-5325.

[12]. T. Ramachandran, , P. Sharma, and K. Balasubramanian. Grain refinement of light alloys. in Proceedings of the 68th WFC-World Foundry Congress, Chennai, India. (2008) 189 193.

[13]. C. Wang, M. Mingxing, B. Yu, D.Chen, P. Qin, M. Feng, Q. Dai., The grain refinement behavior of TiB2 particles prepared with in situ technology. Materials Science and Engineering: A, 459(1-2) (2007) 238-243.

[14]. M. Wang, J-H. Pang, Z-Y. Liu, Z-X. Liu, T-F. Song, S. Yang , Grain refining action of $\mathrm{Ti}$ existing in electrolytic lowtitanium aluminum with $\mathrm{Al}-4 \mathrm{~B}$ addition for superheated $\mathrm{Al}$ melt. Transactions of Nonferrous Metals Society of China, 20(6) (2010) 950-957.

[15]. T. Wróbel, J. Szajnar, The influence of inoculants sort on pure Al structure. J. Achiev. Mater. Manuf. Eng, 50(2) (2012) 206-208.

[16]. X. Xu, Y. Fenga, H. Fanc, Q. Wanga, G. Donga, G. Lia, Z. Zhangd, Q. Liud, X. Fand, H. Ding, The grain refinement of 1070 alloy by different Al-Ti-B mater alloys and its influence on the electrical conductivity, Results in physics, 14 (2019) 102482.

[17]. Y. Wang , C. Fang, L. Zhou, T. Hashimoto, X. Zhou, Q.M Ramasse, Z. Fan, Mechanism for $\mathrm{Zr}$ poisoning of Al-Ti-B based grain refiners. Acta Materialia, 164(11) (2018) 1-12.

[18]. R.S. Rana, R. Purohit, S. Das, Reviews on the influences of alloying elements on the microstructure and mechanical properties of aluminum alloys and aluminum alloy composites, International journal of Scientific and Research Puplications, 2(6) (2012) 1-7.

[19]. X. Dai, C. Xia, X. Peng, K. Ma, Structure and properties of an ultra-high strength $7 x x x$ aluminum alloy contained Sc and Zr. Journal of University of Science and Technology Beijing, Mineral, Metallurgy, Material, 15(3) (2008) 276279.

[20]. T.Shaokun, , L. Jingyuan, Z. Junlong, W. Zhumabieke, L. Dan, Effect of $Z r$ and Sc on microstructure and properties of 7136 aluminum alloy, Journal of Materials Research and Technology, 8(5) (2019) 4130-4140.

[21]. C. Limmaneevichitr, W. Eidhed, , Fading mechanism of grain refinement of aluminum-silicon alloy with Al-Ti-B grain refiners. Materials Science and Engineering A. 349 (2003) 197-206.

[22]. M. Zuo, , M. Sokoluk, , C. Cao, , J. Yuan, S. Zheng, X. Li, Microstructure Control and Performance Evolution of Aluminum Alloy 7075 by Nano-Treating, Sci Rep 9, (2019) 10671. 
[23]. F. Wang, D. Qiu, Z. Liu, J. Taylor,M. Easton, M. Zhang, The grain refinement mechanism of cast aluminium by zirconium, Acta Materialia, 61 (2013) 5636-5645.

[24]. A. E. Mahmoud, M. G. Mahfouz, H. G. Gad- Elrab , M. A. Doheim, Grain refinement of commercial pure aluminum by zirconium. JES, Assiut University, Faculty of Engineering, 42(5) (2014) $1232-1241$

[25]. T. Atamanenko, D. Eskin, M. Sluiter, L. Katgerman, On the mechanism of grain refinement in Al-Zr-Ti alloys. Journal of Alloys and Compounds, 509 (1) (2011) 57-60.

[26]. M. Jaradeh, T. Carlberg, Effect of titanium additions on the microstructure of DC-cast aluminium alloys. Materials Science and Engineering A, 413 (2005), 277-282.

[27]. Y. Zhang, F. Yan, Y.-hong Zhao, C. li Song, H. Hou, Effect of $\mathrm{Ti}$ on microstructure and mechanical properties of die-cast Al-Mg-Zn-Si alloy, Materials Research Express, 7(3) (2020) 036526.

[28]. R.Haghayeghi, Grain refinement and nucleation processes in aluminium alloys through liquid shearing. Brunel University School of Engineering and Design PhD Theses (2009). 